\title{
Development of Interactive Multimedia in Learning to Read Genre Text with Local Wisdom for Students Junior High School Silangkitang
}

\author{
Nurhapni Handayani Optapia \\ Siregar \\ Student Postgraduate Program in \\ Indonesia Language Education \\ UniversitasNegeri Medan \\ nurhapnisiregar4@gmail.com
}

\author{
Abdurahman Adisaputera \\ Lecturer Postgraduate Program in \\ Indonesia Language Education \\ UniversitasNegeri Medan \\ Medan, Indonesia
}

\author{
Amrin Saragih \\ Lecturer Postgraduate Program in \\ Indonesia Language Education \\ UniversitasNegeri Medan \\ Medan, Indonesia
}

\begin{abstract}
Interactive multimedia is a collection of several media such as text, images, audio, video, and animation that are interactive that are used to convey information. Multimedia is the use of several media to present information. This combination can contain text, graphics, animations, images, videos and sounds. Current technology, however, allows educators and students to integrate, combine and interact with media that goes far beyond what was before. Students' understanding of a text in learning is very important in the learning outcomes that will be generated in the learning process. The relevance of reading the description text is closely related to local wisdom. The use of local wisdom themes in reading material means raising local values in students' understanding. This local value will show the identity and identity of the Indonesian people. The development of interactive multimedia is focused on reading material based on local wisdom genres. research that will be conducted by researchers reading the genre of text based on local wisdom will be raised on instructional media in the form of interactive multimedia as an independent teaching medium for students so that the basis of local skills can be raised through teaching media and can be applied in learning activities both through interactive multimedia that is developed or by the teacher.
\end{abstract}

Keywords—development, multimedia, local wisdom, reading

\section{INTRODUCTION}

Interactive multimedia is a collection of several media such as text, images, audio, video, and animation that are interactive that are used to convey information. Ivers \& Ann (in Nopriyanti 2015: 224) [1] explains multimedia is the use of several media to present information. Combinations may include text, graphics, animation, pictures, videos, and sound. Multimedia is the use of several media to present information. This combination can contain text, graphics, animations, images, videos and sounds. Current technology, however, allows educators and students to integrate, combine and interact with media that goes far beyond what was before.

Students' understanding of a text in learning is very important in the learning outcomes that will be generated in the learning process. Based on the test results of each student on one of the materials, namely the description text is still below the Minimum Completion Criteria (KKM) which reaches 75, this is seen from the average results of the seventh grade students' basic competency test results of the description text material over a period of two last year namely: (1) 2016/2017 Learning Year, the average student grade of 63; (2) 2017/2018 learning year the average student score of 65 (Indonesian Language teacher at SMP Negeri I Silangkitang).

The relevance of reading the description text is closely related to local wisdom. In this era of globalization, students must be equipped with a foundation of local wisdom in the area where they live so as not to be confused in laying the groundwork for speaking and acting. One solution that can be used is to introduce local wisdom in the school and home environment because in two places students learn. One of the solutions in introducing local wisdom to students is to provide teaching materials for text genres that are packaged in the form of interactive multimedia. Local wisdom displayed in the reading is close to students' lives so they will feel comfortable reading the description text.

The use of local wisdom themes in reading material means raising local values in students' understanding. This local value will show the identity and identity of the Indonesian people. When information is easily accessible to anyone, local forces will have high selling power and bargaining power. This unique local value will become a selling point in the global community. Almost all local values included in the values of local wisdom can be used as sources and inspiration to enrich the development of life values. Several studies have shown that local wisdom helps communities to survive. According to Ambarita (2016: 68) [2], local wisdom is synonymous with local culture that applies as a pattern of behavior and principles of local community life. Furthermore culture itself is a system that applies in society. Culture is a system that is intended is: adaptive systems, cognitive systems, structural systems of symbols, symbol systems and shared meanings.

Furthermore, Robertus Adi Sarjono Owon (2017) [3] has conducted a research on local wisdom-based text types with the title Development of Teaching Materials Writing Various Types of Texts with the Local Wisdom Themed Wisdom for Middle School Students. In his research the type of text is 
applied to the context of local wisdom learning, but in the research that will be conducted the researcher reads the genre of local wisdom-based text will appear in the instructional media in the form of interactive multimedia as an independent teaching medium for students so that the basis of local skills can be raised through teaching media and is able applied in learning activities both through interactive multimedia developed and by the teacher.

\section{RESEARCH METHODS}

This type of research is research and development, namely the development of reading material to write description texts for junior high school grade. According to Sugiyono (2016: 297) [3], research and development methods are research methods used to produce certain products and test the effectiveness of these products. Tegeh et al (2014: 13) [4], states that development research is a research method that is powerful enough to improve learning practices, with the aim of developing new products or improving existing products so that they can be accounted for. This research and development refers to the theory of reading material development proposed by . The steps of development research according to DDD-E.

The study was conducted at the Junior High School Silangkitang. The research will be conducted from Mei to Juli 2019.

The subjects of the study were students of class VII Junior High School Silangkitang, totaling 32 students and 2 teachers in the field of Indonesian language studies. The object of this research is the development of reading material themed love environment in the description text material for grade VII students of junior high school.

This research is a type of research and development. This research method is used to produce certain products and test the effectiveness of these products. Sugiyono (2010: 407) [5] describes the method of research and development is a research method used to produce certain products and test the effectiveness of these products. Research and Development is a research method that intentionally, systematically, aims or is directed to find, formulate, improve, develop, produce, test the effectiveness of products, models, methods, or strategies, with procedures that are superior, effective, efficient, productive, and meaningful. In this study the handout learning will be developed that are suitable for students' needs. The final objective of this research is to develop a product that can be used, namely interactive learning media that will be evaluated based on the product quality aspects that are determined.

Product Design Interactive Media Learning Text Description can be seen in the following chart:

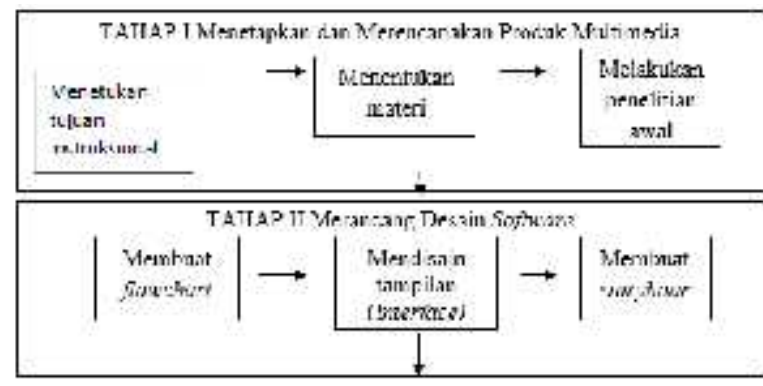

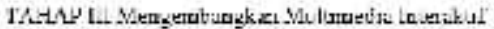

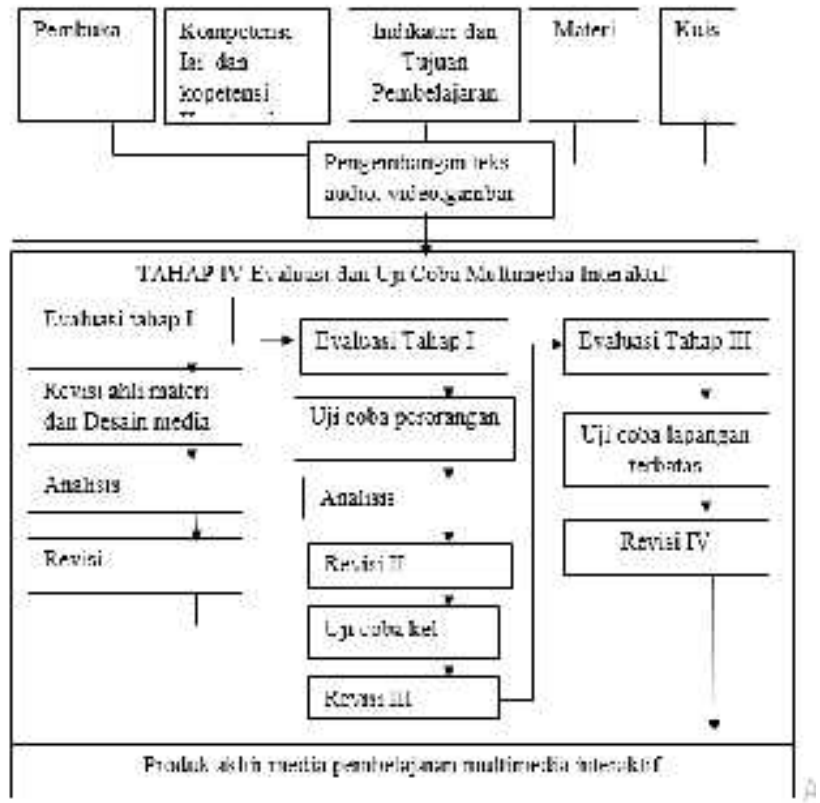

Fig I. Product development chart

Instruments used in this study to collect data are grouped into 2 kinds, namely:

1. Instrument validation team of experts on learning materials reading description text-based troubleshooting methods.

a. The questionnaire validation sheet of the subject matter material

b. Questionnaire design validation master of the questionnaire

2. Instrument responses of students and teachers on teaching materials

a. Individual trial 3 people

b. Trial of small group of 9 people

c. Field trials are limited to 32 people

d. Response Indonesian teacher 2 people

The instrument lattice validation sheet by material experts and design experts can be seen in tables 3.1 and 3.5 below. 
TABLE I. ANALYSIS OF THE INSTRUMENTS OF THE ANGKET FEASIBILITY, THE FEASIBILITY OF THE CONTENT, THE FEASIBILITY OF THE LANGUAGE, AND THE FEASIBILITY OF THE PRESENTATION BY THE EXPERTS

\begin{tabular}{|c|c|c|}
\hline Nu. & Kunpausen Indilaawr Penilaiau & Bangak 3eil \\
\hline \multicolumn{3}{|c|}{ A. Kelavakan Isi } \\
\hline 1 & Kescsualau natern d:nzan K. du KD & 3 \\
\hline$i$ & Keikn:atar mater & 3 \\
\hline 4 & Krmutahran matrr & $?$ \\
\hline 4 & Merdoronz keirgurtziuan & 2 \\
\hline \multicolumn{3}{|c|}{ II. Kelingakan Penyajian } \\
\hline 1 & lickn1k Ponjay:an & 1 \\
\hline 2 & Pencinkung Tenyajian & 6 \\
\hline 3 & T'ungajian Pcmbcla aran & 1 \\
\hline 3 & Koherer:i dan Kernetutar. Alur Berpikir & 1 \\
\hline \multicolumn{3}{|c|}{ C. Kelavalian Bahasa } \\
\hline 1. & Lugls & 3 \\
\hline 2. & Kumuaikilif & 1 \\
\hline 3. & D:shgei: Jari Initraidif & 1 \\
\hline 4. & 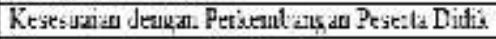 & 2 \\
\hline 5 & Kesesuaian deazar. Kaidas Ialazia & 2 \\
\hline \multicolumn{2}{|r|}{ D. Aspek Pyailaian tema Cinta Linukunzan } & 7 \\
\hline & Jumlah & 37 \\
\hline
\end{tabular}

Data analysis techniques conducted in this development study is this data collected through expert validation, questionnaire distributed to students. Assessment instruments for validations and individual trials, small groups and limited field groups are created in the likert scale that has been scored as in the table below.

TABLE II.CRITERIA ANSWERS INSTRUMENT VALIDATION ITEM WITH LIKERT SCALE

\begin{tabular}{|l|l|l|}
\hline No. & Answer & Scor \\
\hline 1 & Very Good & 4 \\
\hline 2 & Good & 3 \\
\hline 3 & Not Good & 2 \\
\hline 4 & Poorly & 1 \\
\hline
\end{tabular}

(Sugiyono, 2016: 93)[6]

Then the data is analyzed descriptively quantitative, that is calculated percentage of indicator for each category on instructional material developed.

\section{$\%$ skor $=\frac{\text { number of indicators per category }}{\text { the number of indicators of all categories }} \times 100 \%$}

Based on the calculation of the formula above, the figure is generated in percent. The classification of the score is then changed to classification in the form of percentage (Sugiyono, 2011: 118)[7], then interpreted with qualitative sentences.

\section{RESEARCH RESULT}

Based on the formulation, objectives, results and discussion of teaching materials development research in the form of reading descriptoin text on learning proposed.

Based on the formulation, objectives, results and discussion of teaching materials development research in the form of reading description texton learning proposed.previously mentioned, it can be concluded discussion and research results as follows. At the beginning of the study will spread questionnaire needs analysis to 34 respondents, consisting of 32 students and 2 teachers.

Based on the data needs analysis by students obtained the following conclusions:

1. All teachers and students (100\%) said they were familiar with the reading description textmedia based on problem solving.

2. All teachers and students $(100 \%)$ stated that they do not use learning-based reading description textinteractive media on learning in the learning process and never use the media.

3. All teachers and students (100\%) stated needing reading description textinteractive media on learning proposed.

The validation result from the material expert, in the form of scoring score on learning component of reading description text of interactive media on learning, can be known through the assessment done by the material expert from the quality aspect of the learning media which includes the quality of the content feasibility, feasibility of presentation, language feasibility, and feasibility interactive media on learning is rated "excellent" with the percentage of scores for validation scores from material experts is $95.08 \%$.

The validation results of the design experts, in the form of scoring scores on the learning component of reading description textof interactive media on learning, can be known through the appraisal done by the design expert from the quality aspect of the learning media that the aspect of the feasibility of grading is considered "excellent" with the percentage of scores for the validation score from design expert is $86.96 \%$.

The validation result from the material expert, in the form of scoring score on learning component of reading description text of interactive media on learning, can be known through the assessment done by the material expert from the quality aspect of the learning media which includes the quality of the content feasibility, feasibility of presentation, language feasibility, and feasibility based on method problem solving is rated "excellent" with the percentage of scores for validation scores from material experts is $95.08 \%$.

The validation results of the design experts, in the form of scoring scores on the learning component of reading description textof interactive media on learning, can be known through the appraisal done by the design experts from the quality aspect of the learning media that the aspect of the feasibility of the grading is considered "excellent" with the percentage of scores for the validation score from design expert is $86.96 \%$.

Very good quality individual test $(94,76 \%)$, very good small group test $(97,64 \%)$ and last assessment of field test with excellent quality $(96,20 \%)$, result of effectively test to student studying using learning based interactive is indicated by the results of data processing obtained value " $t$ ", then matched with the table at a significant level of $5 \%=1.66$. This proves that $\mathrm{t}$ count $<\mathrm{t}$ table is $1.66<4.07$. Thus, it is concluded that the development of instructional materials in the form of learning medias on reading description text learning is very feasible, 
easy and effective to used on learning text explanation in high school class XI.

\section{CONCLUSION}

Instrumental in the learning process. The development of teaching materials needs to be done in an effort to improve learning outcomes and establish the material based on the context of the situation in the school. Teaching materials have a very important position in learning, namely as a representation of the teacher's explanation in front of the class. Factors that cause the learning material explanation text conducted by teachers in the classroom is still less interesting and monotonous is the teacher still using conventional materials that are oriented on the results of students, not on the learning process so that students are only given theories of writing and forced to understand the material, while still there are students who have not understood about the material of reading description text and its concept. The accuracy of teachers in choosing, applying and developing teaching materials used in reading description text materials greatly affect the learning process, but in this case the teacher is still not quite right.

Based on the theory, the development of teaching materials in the form of reading description textwith interactive media is needed to support students in improving knowledge in reading description text material. This media is also needed to support the progress of student learning outcomes in reading description text material. The media is also developed with interactive media, this method will serve as the color and characteristic of the media developed and make the media increasingly attract students' attention. The development of this learning media is a programmable development in a systematic sequence and meets the characteristics to support students in learning. The last test subject of two Indonesian subject matter experts, two design instructional experts, three students for individual testing, nine students for small group test and thirtytwo students for field test. Data about the quality of this development product were collected by questionnaire with the result of the research showed that the experimental material was very good $(95,08 \%)$, the test of the excellent category learning to design expert $(86,96 \%)$, the excellent quality individual test $(94,76 \%)$, very good small group test $(97,64 \%)$ and last assessment of field test with very good quality $(96,20 \%)$, result of effectively test to student learning to use problem-based learning media is shown with result of data processing obtained value " $\mathrm{t}$ ", then matched with table at significant level $5 \%=1.66$. This proves that $\mathrm{t}$ count $<\mathrm{t}$ table is $1.66<4.07$. Thus, it was concluded that the development of teaching materials in the form on learning description text of class VII junior high school.

\section{REFERENCES}

[1] Nopriyanti. 2015. Pengembangan Multimedia Pembelajaran Interaktif Kompetensi Dasar Pemasangan Sistem Penerangan dan Wiring Kelistrikan di SMK. Jurnal Pendidikan Vokasi: Universitas Negeri Yogyakarta.

[2] Ambarita, Biner. (2016). Manajemen Pendidikan dan, Peningkatan Mutu. Bandung: Alfabeta

[3] Sugiyono. 2016. Metode Penelitian Kuantitatif, Kualitatif dan R\&D. Bandung: Alfabeta.

[4] Tegeh, Made Dkk.2014. Model Penelitian Pengembangan. Yokyakarta: Graha

[5] Sugiyono. 2010. Metode Penelitian Kombinasi (Mixed Methods). Bandung: Alfabeta.

[6] Sugiyono. 2016. Metode Penelitian Kombinasi (Mixed Methods). Bandung: Alfabeta

[7] Sugiyono. 2011. Metode Penelitian Kombinasi (Mixed Methods). Bandung: Alfabeta 